\begin{tabular}{|l|l|l|l|l|l|}
\hline J. Tek. Ling & Vol. 13 & No. 2 & Hal. 203-211 & Jakarta, Mei 2012 & ISSN 1441-318X \\
\hline
\end{tabular}

\title{
SISTEM KULTIVASI ORGANIK PADA KACANG TANAH (Arachis hypogea L.) DENGAN MEMANFAATKAN TINGKAT KEMATANGAN KOMPOS
}

\author{
1Dwi Agustiyani , ${ }^{2}$ Budhi Martono dan ${ }^{1}$ Maman Rahmansyah \\ 'Bidang Mikrobiologi, Pusat Penelitian Biologi LIPI, \\ Cibinong Science Center, Jl. Raya Jakarta Bogor km 46, Cibinong 16911 \\ ${ }^{2}$ Balai Penelitian Pertanian, Departemen Pertanian, \\ Jl. Tentara Pelajar, Cimanggu, Bogor \\ E-mail: titinagustin@yahoo.com
}

\begin{abstract}
Abstrak
Untuk mendukung suatu sistem pertanian yang berkelanjutan, praktek pertanian organik dilakukan pada kultivasi kacang tanah. Pada penelitian ini, pengkombinasian antara penggunaan bakteri pelarut fosfat (Pseudomonas $s p$.), bakteri penambat nitrogen (Rhizobium spp.), dan fungi pendegradasi selulosa (Trichoderma sp. dan Aspergillus $s p$.) digunakan untuk inokulan. Kompos berupa bahan hijauan daun dan limbah kotoran ternak kemudian diformulasikan dengan inokulan untuk digunakan sebagai pupuk hayati. Kompos-matang dan kompos-setengah-matang fermentasi digunakan untuk pengkayaan hara tanah. Penggunaan kompos setengah matang merupakan praktek semi-on-site-composting di dalam upaya menstimulasi pertum-buhan tanaman. Pengaruh perlakuan pada penelitian ini dievaluasi melalui pertum-buhan tanaman dan hasil polong. Tidak didapat perbedaan yang signifikan di antara perlakuan pupuk hayati, namun seluruh perlakuan memperlihatkan perbedaan yang nyata terhadap kontrol. Oleh sebab itu, praktek pengunaan kompos setengah matang mampu mempersingkat persiapan tanam dan dapat diterapkan pada kultivasi kacang tanah. Penggunaan kompos separuh matang hasil penelitian ini dapat dipraktekan di dalam pengembangan tehnik kultivasi untuk mendukung sistem pertanian berkelanjutan.
\end{abstract}

Kata kunci : pupuk hayati, semi-on-site-composting, sistem pertanian berkelanjutan, Arachis hypogea L.

\begin{abstract}
In order to support a sustainable agriculture system, an organic farming purpose had been carried out all through groundnut cultivation. In this experiment, the combination of phosphate solubilizing bacteria (Pseudomonas sp.), fixing nitrogen bacteria (Rhizobium spp.), and fungal degrading cellulose (Trichoderma sp. and Aspergillus sp.) were used as inoculant. Organic substrate as a green manure compost and cattle waste was mixing with the inoculant to utilize into biofertilizer improvement. Full and half fermented compost materials designed for soil augmentation. Half fermented compost materials exploited to semi-on-site-composting practice in appropriate to fuel plant growth. Result of the treatment evaluated through plant growth and the pods yield. There have not significant different among biofertilizer handling, and all have the exclusion to the control. As due
\end{abstract}


to that practice, then semi-on-site-composting would be restrain in pre-agriculture processing time and exploitable to groundnut cultivation. The half ripe composting in this observation will be relevance in practical agriculture technique to affect sustainable agriculture development.

Key words : biofertilizer, semi-on-site-composting, sustainable agriculture system, Arachis hypogea $L$.

\section{PENDAHULUAN}

\subsection{Latar Belakang}

Dalam mencapai kesinambungan suatu produksi pertanian, pupuk organik dan pupuk hayati memainkan peran penting karena berhubungan dengan ketersediaan nutrisi tanah yang diper-lukan tumbuhan. Selain itu, fungsi kedua pupuk tersebut menguntungkan dalam memperbaiki karakteristik fisik, kimia dan sifat biologi tanah. Namun, dosis efektif penggunaan pupuk organik dan pupuk hayati untuk jenis tanaman ataupun jenis tanah tertentu memerlukan pengamatan dan penelitian sehingga ketika digunakan untuk kultivasi tumbuhan maka dosis yang tepat semestinya dapat diperhi-tungkan ${ }^{1}$. Informasi hasil penelitian penggunaan pupuk organik di suatu wilayah terhadap komoditas tertentu dapat menjadi acuan di dalam pelaksa-naan manajemen budidaya komoditas pertanian selanjutnya ${ }^{2)}$.

Proses mineralisasi nitrogen $(\mathrm{N})$ atau penurunan $\mathrm{C} / \mathrm{N}$ rasio terjadi di tanah ketika ada penambahan residu tum-buhan, selain juga berpengaruh terhadap kondisi diversitas mikroba di tanah ${ }^{3)}$. Pengembalian bahan organik ke tanah, khususnya di lingkungan lahan pertanian intensif adalah sebagai upaya menyeim-bangkan keberadaan karbon ${ }^{4,5)}$. Keter-sediaan bahan organik tanah juga menjamin efisiensi penggunaan air oleh tanaman selama proses pertumbuhan-nya ${ }^{6}$.

Keberhasilan pemanfaatan pu-puk hayati memerlukan mikroba yang memiliki sifat unggul. Kemampuan bakteri pelarut fosfat (phosphat solubilizing bacteria = PSB) menguntungkan baik secara langsung dan tidak langsung kepada tumbuhan ${ }^{7}$. Efek tidak langsung yaitu dapat menurunkan atau mencegah mikroba patogen karena sintesis antibiotik ${ }^{8)}$, dan memproduksi zat siderophores ${ }^{9}$. Efek langsung yang terja-di adalah melalui sintesis fitohormon ${ }^{10)}$, fiksasi nitrogen ${ }^{11)}$, menurunkan membran potensial $a{ }^{12)}$, sintesis enzim ${ }^{13)}$, serta bersifat melarutkan fosfat anorganik dan melakukan mine-ralisasi sehingga menghasilkan fosfor yang tersedia bagi tanaman ${ }^{14)}$. Keseluruhan mekanisme tersebut mendorong peningkatan energi untuk penyerapan nutrisi oleh tanaman.

Mikroba pendegradasi senyawa karbon selain menguntungkan untuk mendukung kusuburan tanah di daerah perakaran, juga memiliki nilai positif lain untuk membersihkan polutan kimia agro. Residu kimia pestisida yang mengan-dung bahan dasar senyawa karbon, dapat dimanfaatkan mikroba tertentu sebagai sumber karbon dalam sistem metabolismenya. Untuk itu, mikroba tanah yang mampu melarutkan $P$ organik dan mengikat $\mathrm{N}$ bebas serta tahan dan juga mampu merombak polutan kimia agro adalah tepat untuk menjadi sumber pupuk hayati. Hal tersebut bertujuan mengoptimalkan dalam penggunaan mikroba karena selain berfungsi sebagai perombak dan meningkatkan keterse-diaan hara yang diperlukan tumbuhan, juga sekaligus membersihkan polutan. Penyatuan fungsi dan peran mikroba sebagai bahan pupuk hayati pada hakikatnya adalah menyatukan berbagai karakter fisiologis seperti berkait dengan penyediaan unsur hara, sebagai agen biokontrol, serta selaku agen perombak dan pendegradasi polutan. Sehubungan dengan upaya penggunaan pupuk organik dan pupuk hayati yang bisa diaplikasikan 
secara tepat maka upaya penelitian telah dilakukan pada kultivasi tanaman kacang tanah (Arachis hypogea L.). Perkembangan komponen tumbuh tanaman menjadi parameter dalam mengukur keberhasilan penggunaan pupuk kompos dan inokulan tersebut.

\subsection{Tujuan Penelitian}

Tujuan dari penelitian adalah untuk mempertegas fungsi mikroba simbion yang aplikasinya dilakukan melalui penggunaan pupuk hayati dan sekaligus mengetahui kemungkinan munculnya fungsi antagonis yang memang tidak dikehendaki. Sedangkan penggunaan bahan organik dimaksudkan untuk menyeimbangkan ketersedian sumber karbon di tanah.

\section{METODOLOGI}

Bahan kompos terdiri atas limbah kebun berupa potongan rumput, kotoran sapi, dan daun Kaliandra (Calliandra calothyrsus Meissn.) sebagai tambahan sumber $\mathrm{N}$, dengan perbandingan masingmasing 6, 3, dan 1 bagian. Kompos yang dipersiapkan meliputi kompos yang telah mengalami degradasi penuh, dan yang lainnya menggunakan kompos yang hanya mencapai setengah proses pengomposan atau setengah matang yang dalam kegunaannya mendukung praktek semi-onsite-composting.

Inokulan berasal dari beberapa isolat bakteri pelarut fosfat (BPF) yaitu Pseudomonas sp., bakteri penambat nitrogen (BPN), dan jamur perombak bahan organik (PBO), seperti tertera pada Tabel 1. Masing-masing isolat mikroba ditumbuhkan pada media cair yang digunakan sebagai sumber isolat. Setiap satu liter isolat cair dengan kepadatan setara dengan 1.109 CFU (colony forming unit) dicampurkan dengan $10 \mathrm{~kg}$ kompos.

Penelitian dilakukan di lahan pertanian dataran tinggi (900 m dpl) Cisarua pada periode April sampai Juli 2007. Perlakuan diatur menurut rancangan petak terpisah (Split Plot) dengan petak utama adalah perlakuan Nodulin (inokulan Rhizobium), sedangkan anak petaknya adalah perlakuan kompos. Benih kacang ditanam di petak penelitian masing-masing berukuran 300 x $150 \mathrm{~cm}$. Pemberian kompos untuk setiap petak adalah setara dengan $4 \mathrm{~kg}$ per $\mathrm{m}^{2}$. Rancangan penelitian diatur seperti pada Tabel 2, dengan perlakuan utama adalah tanpa inokulan Rhizobium (N0) dan dengan inokulan (N1); sedangkan anak petak adalah kualitas kompos, yaitu yang terdiri

Tabel 1. Isolat yang dipergunakan untuk bahan pupuk hayati

\begin{tabular}{|c|c|c|c|c|c|c|c|}
\hline \multirow{2}{*}{ No } & \multirow{2}{*}{ No Isolat } & \multicolumn{3}{|c|}{ Pendegradasi } & \multirow{2}{*}{$\begin{array}{c}\text { Fiksasi } \\
\mathrm{N} \\
\end{array}$} & \multirow{2}{*}{\begin{tabular}{|c|} 
Pelarut \\
$\mathrm{P}$ \\
\end{tabular}} & \multirow{2}{*}{$\begin{array}{c}\text { Asal koleksi/Nama } \\
\text { inokulum }\end{array}$} \\
\hline & & Pestisida* & Sianida & Organik & & & \\
\hline 1. & $\mathrm{~K} . \mathrm{AOH} 1$ & + & - & - & - & + & $\begin{array}{l}\text { Kalimantan (tanah } \\
\text { pertanian)/BPF }\end{array}$ \\
\hline 2. & PIKO I & + & - & - & - & + & $\begin{array}{l}\text { Cipanas (tanah } \\
\text { pertanian)/BPF }\end{array}$ \\
\hline 3. & CktGN & + & + & - & + & + & $\begin{array}{l}\text { Cikotok (lokasi } \\
\text { penampungan limbah } \\
\text { tambang emas)/BPN }\end{array}$ \\
\hline 4. & R. leguminosarum & - & - & - & + & - & Koleksi LIPI-MC/BPN \\
\hline 5. & Aspergillus sp. & - & - & + & - & - & Koleksi LIPI-MC/PBO \\
\hline 6. & Trichoderma sp. & - & - & + & - & - & Koleksi LIPI-MC/PBO \\
\hline
\end{tabular}

*Sevin 
Tabel 2. Perlakuan (notasi K) pada penelitian dinyatakan dengan lambang positif

\begin{tabular}{|l|l|c|c|c|c|c|c|c|c|}
\hline \multirow{2}{*}{ No. } & \multirow{2}{*}{ Perlakuan } & \multicolumn{3}{c|}{ Tanpa BPN (N0) } & \multicolumn{3}{c|}{ Dengan BPN (N1) } \\
\cline { 3 - 13 } & & K0 & K1 & K2 & K3 & K0 & K1 & K2 & K3 \\
\hline 1 & Kompos matang & - & - & - & + & - & - & - & - \\
\hline 2 & Kompos setengah matang & - & + & + & - & - & + & + & + \\
\hline 3 & K.A0H1 (Bakteri Pelarut Fosfat/BPF) & - & + & + & + & - & + & + & + \\
\hline 4 & PIKO I (Bakteri Pelarut Fosfat/BPF) & - & + & + & + & - & + & + & + \\
\hline 5 & CktGN (Bakteri Penambat Nitrogen /BPN) & - & - & - & - & + & + & + & + \\
\hline 6 & Rhizobium leguminosarum (BPN) & - & - & - & - & + & + & + & + \\
\hline 7 & Aspergillus sp. (perombak organik) & - & - & + & - & - & - & - & + \\
\hline 8 & Trichoderma sp. (perombak organik) & - & - & + & - & - & - & - & + \\
\hline
\end{tabular}

atas kompos $1 / 2$ matang (K1), kompos $1 / 2$ matang yang diberi Trichoderma sp. dan Aspergillus sp. (K2), kompos matang (K3), dan lahan kontrol sebagai lahan yang tidak mendapat perlakuan kompos (K0). Setiap perlakuan pada pengamatan menggunakan tiga ulangan. Hasil rata-rata perlakuan dilanjutkan dengan uji Duncan's Multiple Range Test (DMRT) pada tingkat $5 \%$.

\section{HASIL DAN PEMBAHASAN}

Hasil pengamatan meperlihatkan bahwa perlakuan pemberian pupuk organik sangat berpengaruh terhadap parameter pengamatan seperti tinggi tanaman dan pertambahan jumlah daun selama pengamatan 12 minggu. Pengaruh pemberian inokulan Rhizobium tidak kelihatan beda nyata pada awal pertumbuhan. Perbedaan pengaruh perlakuan baru nampak terhadap pengamatan tinggi tanaman pada minggu ke 6 dan 9 minggu setelah tanam (MST), sedangkan pada jumlah helai anak daun terlihat nyata pada pengamatan 9 dan 12 MST. Hal demikian mengindikasikan bahwa bakteri Rhizobium asli (indigenous) memang telah tersedia memadai dan efektif, dengan tidak didapatnya per-bedaan yang nyata antara kontrol dan perlakuan. Perlakuan pemberian kompos ( $\mathrm{K} 1, \mathrm{~K} 2$, dan $\mathrm{K} 3$ ) yang disertai perlakuan pupuk hayati (BPF,
BPN, dan BPO) terlihat beda nyata pada pengamatan pertumbuhan 12 MST. Pada hasil penga-matan sebelumnya (3 MST) menunjuk-kan bahwa efek perlakuan pada awal pertumbuhan belum terlihat beda nyata dengan tanaman kontrol. Hasil hitungan statistik dan gambaran pertumbuhan akibat interaksi perlakuan ditampilkan pada Gambar 1. Efek perlakuan terhadap hasil akhir diukur berdasar bobot biomasa tanaman dan jumlah polong. Perlakuan utama pemberian inokulan Rhizobium memperlihatkan hasil yang tidak berbeda nyata pada hasil penelitian ini (Tabel 3).

Bakteri penambat nitrogen asli berperan dominan menjelang pertumbu-han generatif, dan bakteri yang ditam-bahkan hanya berpengaruh pada awal pertumbuhan saja. Peran mikroba sim-bion penambat $\mathrm{N}$ indigen ditunjukkan dengan terbentuknya bintil akar pada kelompok tanaman kontrol (Gambar 2).

Pengaruh perlakuan kompos terhadap hasil biomasa sangat berbeda dari kontrolnya. Kompos setengah matang yang diberi jamur pendegradasi bahan organik (PBO) menghasilkan tanaman dengan sel tumbuhan yang lebih masif dari perlakuan lainnya yang ditunjukkan dengan memiliki bobot biomasa tertinggi. Sedangkan untuk hasil polong tertinggi di antara perlakuan adalah karena pemberian kompos matang (K3). Perbedaan pengaruh seluruh perlakuan kompos terhadap kontrol-nya semakin 
terlihat pada hasil polong. Pada kelompok kontrol terdapat jumlah polong yang kosong atau cipo dengan jumlah yang lebih banyak. Jumlah polong cipo lebih banyak pada tanaman yang tidak mendapatkan inokulan BPN diban-dingkan dengan yang diberi perlakuan inokulan tersebut (Gambar 3). Korelasi bobot basah terhadap bobot kering polong bernilai signifikan, kelompok kontrol sangat nyata terlihat berbeda dari seluruh perlakuan.

Pemberian kompos jerami padi dengan penambahan inokulan Rhizobium fredii dan Bradyhrizobium sp., yang kemudian dikombinasikan dengan pemupukan NPK menyebabkan kualitas isi dan tingkat serapan hara oleh tanaman kedelai meningkat. Ketersediaan nitro-

\begin{tabular}{|c|c|c|c|c|}
\hline \multirow{2}{*}{ Pertakuan } & \multicolumn{4}{|c|}{ Mingeu ke } \\
\hline & 3 & 6 & 9 & 12 \\
\hline \multicolumn{5}{|l|}{ Petak Utams } \\
\hline N2 itanpa Rhizobium! & 24.18 & 22.18 & 29.62 & 23.13 \\
\hline N1 (dengen Nhioobium) & 13.08 & 19.42 & 26,47 & 3400 \\
\hline homeg $N$ & $1.72^{\circ}$ & $2725^{\circ}$ & $8.86^{\circ}$ & $0.11^{2}$ \\
\hline \multicolumn{5}{|l|}{ Andi Petak } \\
\hline Ko (tances koeroos) & $13.03^{*}$ & $17.49^{\circ}$ & $21.22^{*}$ & $29.00^{\circ}$ \\
\hline Ka (kompos Ki matand) & 13.370 & $235 a^{2}$ & 29.450 & $37.00^{\circ}$ \\
\hline 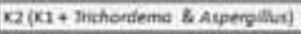 & $13.33^{\circ}$ & $20.37 \%$ & $3052^{\circ}$ & $3642^{2}$ \\
\hline K3 (hompos matand) & $1450^{4}$ & $21.85^{\circ 0}$ & $30.58:$ & $3233^{21}$ \\
\hline Finas $x$ & $1.17=$ & $5.93^{*}$ & $10.19^{* *}$ & 4.15 \\
\hline fours interabi & $102^{2}$ & $1.61^{*}$ & $0.74=$ & $1.49^{*}$ \\
\hline
\end{tabular}

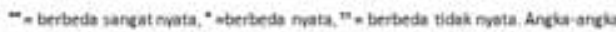

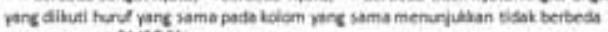
nyata menuns OMkT'st.

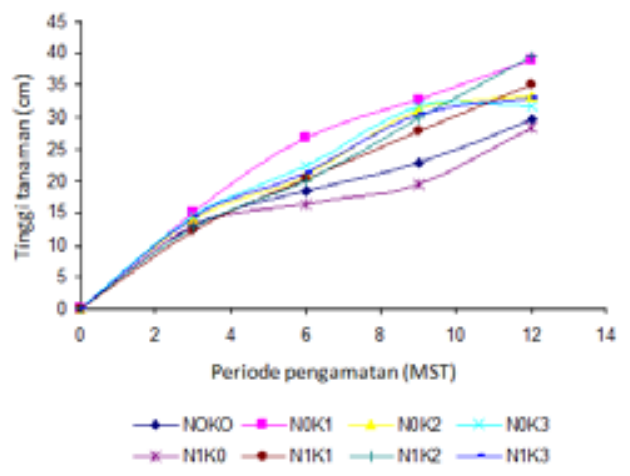

Tinggi Tanaman (cm) gen, fosfor dan kalium di tanah juga naik sebagai efek langsung penggunaan kompos jerami ${ }^{1}$. Pada penelitian ber-ikutnya, proses pengomposan jerami padi hasil degradasi jamur Trichoderma sp. kemudian diberi tambahan inokulan bakteri penambat nitrogen (Gluco-nacetobacter diazotrophicus, Bradyrhizo-bium japonicum, Bradyrhizobium spp) serta bakteri pelarut fosfat (Pseudomonas syringae). Pemanfaatan pupuk hayati yang disiapkan di awal tanam tersebut kemudian diterapkan pada sistem tanam padi - kedelai - kacang tanah. Praktek budidaya tersebut apabila kemudian dibantu dengan aplikasi pupuk $\mathrm{N} 60$ - $70 \mathrm{~kg}$ dan pupuk P2O5 $60 \mathrm{~kg} / \mathrm{ha}$ ternyata bisa meningkatkan perolehan kalkulasi ekonomi yang lebih mengun-tungkan. Kualitas produk tidak

\begin{tabular}{|c|c|c|c|c|}
\hline \multirow{2}{*}{ Pertakuan } & \multicolumn{4}{|c|}{ Mingeuke } \\
\hline & 3 & 6 & 9 & 12 \\
\hline \multicolumn{5}{|l|}{ Petak Utarno } \\
\hline No itanpa fhiasbium! & 1232 & 3967 & 5.58 & 7550 \\
\hline N1 (dengan Nhoobium) & 12.33 & 33.83 & 63.33 & 84.58 \\
\hline honet $N$ & $0.75^{\prime \prime}$ & $4.8 a^{2}$ & $8.04^{*}$ & $9.79^{\circ}$ \\
\hline \multicolumn{5}{|l|}{ Ansik Petak } \\
\hline Ko (tanca komoos) & $9.00 \%$ & 27570 & $4367^{\circ}$ & $6250^{\circ}$ \\
\hline K1 (kompos Ki matant) & $14.00^{\circ}$ & $39.57^{\circ}$ & $6217 *$ & $8133^{*}$ \\
\hline 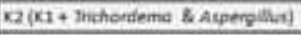 & $1350^{\circ}$ & $39.00^{\circ}$ & $68.00 \div$ & $9100^{\circ}$ \\
\hline K3 (hompos matana) & $14.00^{*}$ & $40.67 *$ & $70.00^{\circ}$ & $35.33^{*}$ \\
\hline Fing $x$ & $4.66^{\circ}$ & $5.19^{\circ}$ & $8.78 *$ & $15.25{ }^{\circ}$ \\
\hline fow interaki & $024=$ & $0.77+$ & $3.15=$ & $413^{+}$ \\
\hline
\end{tabular}

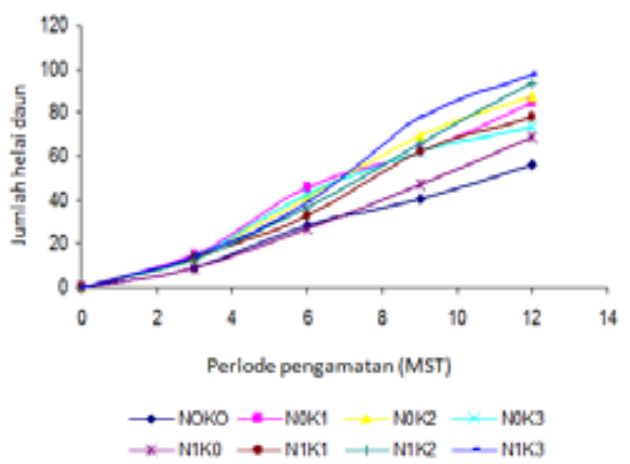

Pertumbuhan Jumlah Daun

Gambar 1. Efek perlakuan terhadap pertumbuhan (notasi perlakuan seperti pada Tabel 2) 
Tabel 3. Pengaruh perlakuan terhadap hasil akhir tanaman

\begin{tabular}{|l|c|c|c|c|}
\hline \multicolumn{1}{|c|}{ Perlakuan } & \multicolumn{2}{c|}{ Jumlang polong } & \multicolumn{2}{c|}{ Biomasa tumbuhan (g) } \\
\hline & Bernas & Cipo & Segar & Kering \\
\hline Petak Utama & \multicolumn{5}{|l|}{} \\
\hline N0 (tanpa Rhizobium) & 19.33 & 10.13 & 33.92 & 14.63 \\
\hline N1 (tambah Rhizobium) & 21.63 & 6.08 & 35.50 & 16.50 \\
\hline Fhitung N & 0.85 tn & 7.57 tn & 0.08 tn & 1.47 tn \\
\hline Anak Petak & $8.92 \mathrm{a}$ & $7.57 \mathrm{a}$ & $14.70 \mathrm{a}$ & $8.00 \mathrm{a}$ \\
\hline K0 (tanpa kompos) & $24.83 \mathrm{~b}$ & $8.00 \mathrm{a}$ & $40.72 \mathrm{~b}$ & $18.00 \mathrm{~b}$ \\
\hline K1 (kompos $1 / 2$ matang) & $22.58 \mathrm{~b}$ & $8.58 \mathrm{a}$ & $41.71 \mathrm{~b}$ & $18.33 \mathrm{~b}$ \\
\hline $\begin{array}{l}\text { K2 (K1 + Trichordema \& } \\
\text { Aspergillus) }\end{array}$ & $25.58 \mathrm{~b}$ & $10.08 \mathrm{a}$ & $41.72 \mathrm{~b}$ & $17.92 \mathrm{~b}$ \\
\hline K3 (kompos matang) & $11.35^{\star *}$ & $1.47 \mathrm{tn}$ & $29.87^{* *}$ & $11.01^{* *}$ \\
\hline Fhitung K & $0.56 \mathrm{tn}$ & $0.66 \mathrm{tn}$ & $2.34 \mathrm{tn}$ & $1.26 \mathrm{tn}$ \\
\hline Fhitung interaksi
\end{tabular}

$=$ berbeda sangat nyata,. berbeda nyata, $\mathrm{tn}$ = berbeda tidak nyata. Angka-angka yang diikuti

huruf yang sama pada kolom yang sama menunjukkan tidak berbeda nyata menurut DMRT $5 \%$

hanya diperoleh pada perolehan panen yang lebih tinggi, namun juga dari sisi kualitas seperti dari hal kandungan lemak dan protein biji turut meningkat. Pola kombinasi penggunaan pupuk hayati dan pupuk kimia dapat mempertahankan keterse-diaan hara juga mampu menjaga kelang-sungan hidup mikroba tanah yang bermanfaat lainnya seperti populasi jamur, Azotobacter dan Actinomycetes ${ }^{15}$. Sistem agronomi seperti ini direko-mendasikan menjamin terciptanya kegiatan pertanian yang berkelanjutan. Pola tanam kacang tanah yang dilakukan melalui pengamatan ini mengandalkan pencampuran kompos, pupuk kandang dan inokulan mikroba pada dosis setara dengan $4 \mathrm{~kg}$ pupuk hayati per meter persegi. Tujuan dan manfaat praktek pemupukan yang dilakukan supaya dapat menjaga ketersediaan nutrisi pada kegiatan tanam berikutnya dengan hanya menerapkan pola pemupukan minimal dalam bentuk pupuk organik, pupuk hayati, maupun pupuk kimia.

Kompos yang diberi pupuk kan-dang dengan rasio volume seimbang akan menjadi lebih baik untuk mengha-silkan produktivitas tanaman kacang tanah apabila dibandingkan dengan tanpa pemberian pupuk kandang ${ }^{16)}$. Hasil tana-man yang diukur melalui komponen biomasa dan kualitas biji ternyata mem-berikan hasil yang tertinggi ketika pada kompos yang dicampur pupuk kandang tersebut juga diberikan tambahan inokulan bakteri pelarut fosfat. Bahan kompos yang digunakan dan berasal dari tanaman halopitik Suaeda maritima (L.) Dumort., Sesuvium portula-castrum L. dan Ipomoea pescaprae (L.) ketiganya menghasilkan kompos dengan kualitas berbeda. Bahan kompos terbaik dihasilkan ketika menggunakan bahan tumbuhan Suaeda ${ }^{17)}$. Efektifitas peng-gunaan kompos terkait dengan pasokan nutrisi penting yang terjadi akibat proses mineralisasi pupuk organik secara menerus, selain terjadinya peningkatan kapasitas tanah yang bisa mendukung ketersediaan nutrisi karena efek yang menguntungkan dari meningkatnya sifat fisik dan biologi tanah.

Perlakuan Trichoderma dan pemberian kapur pada praktek agronomi kacang tanah dapat menekan kehadiran Aspergillus 

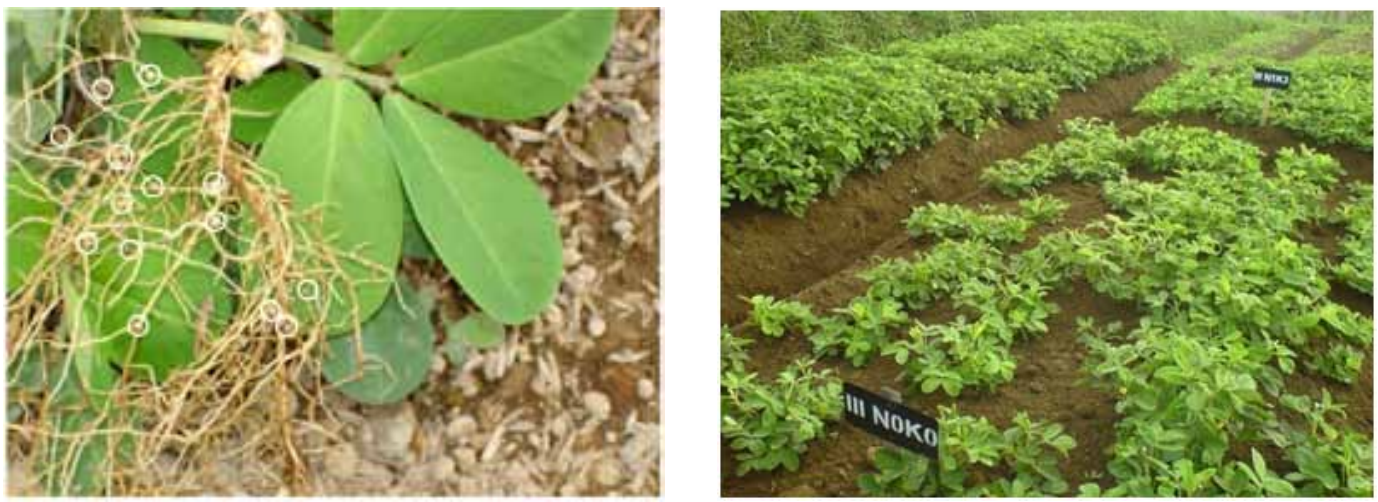

Gambar 2. Tanaman kontrol (NOKO) membentuk bintil (dalam tanda lingkar putih) pada umur 2 MST (foto kiri), dan tanaman kontrol di lapangan berumur 6 MST (foto kanan)
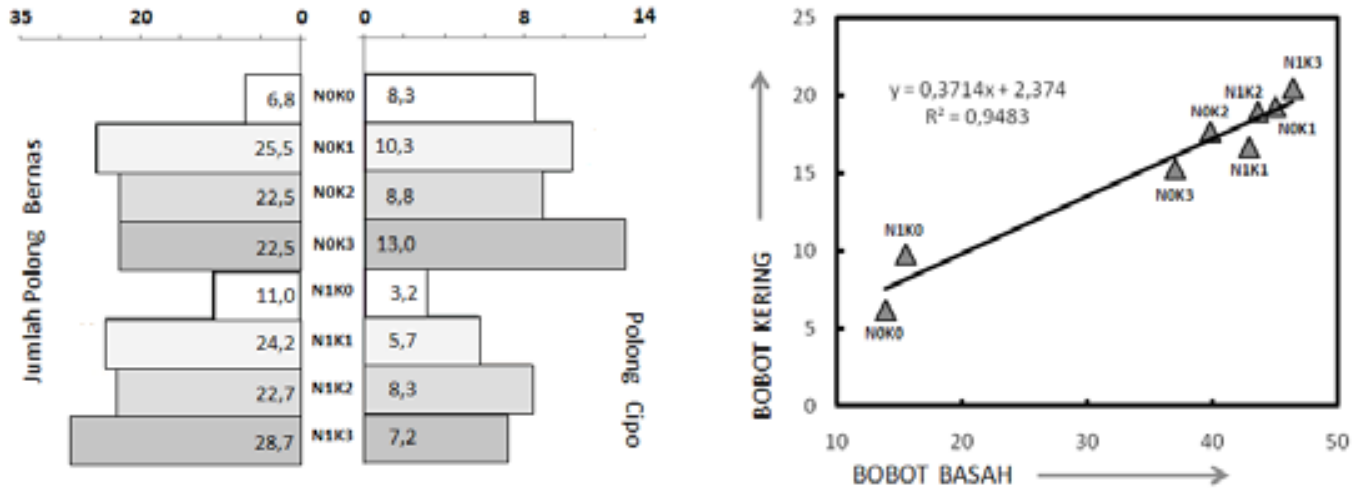

Gambar 3. Hasil pengamatan parameter kualitas polong $(\mathrm{r} 0.001=0.898)$

yang tidak dikehendaki karena dapat mengganggu kualitas polong dan biji kacang saat pasca panen. Penekanan populasi Aspergillus ini penting dalam menghindari terjadinya kontaminasi zat racun aflatoksin ${ }^{18)}$. Penggunaan biopestisida menjadi alter-natif lain dalam upaya pemberantasan hama pada budidaya kacang tanah. Ekstrak tumbuhan Azadirachta indica A Juss dari daun dan biji dapat berfungsi sebagai insektisida dan yang pernah dipraktekan di India pada tanaman dewasa maupun sebagai mikosida untuk menekan pertumbuhan jamur Alternaria spp. yang biasanya menyerang tanaman kacang pada tingkat kecambah ${ }^{19}$. Banyak sumberdaya tumbuhan Indone-sia yang bisa dimanfaatkan untuk pem-berantasan hama kacang tanah sebagai tindak pencegahan terhadap pencema-ran kimia agro.

\section{KESIMPULAN}

1. Praktek pemanfaatan kompos setengah matang dapat diterapkan pada budidaya kacang tanah sehingga menyingkat waktu persiapan yang lebih pendek.

2. Peran mikroba fungsional simbion menunjukkan peran nyata yang ditunjukkan oleh hasil beda nyata terhadap kontrolnya pada parameter yang diamati.

3. Perlu dilakukan perifikasi efek ketersediaan hara pada praktek kegiatan agronomi lanjutan terkait dengan efisiensi penggunaan pupuk organik hayati pada kegiatan tanam berikutnya. 


\section{DAFTAR PUSTAKA}

1. Son, T.T.N., V. Thu, T.L. Man and H. Hiraoka 2001. Effect of organic and biofertilizer on quality, grain yield and soil properties of soybean under rice based cropping system. Omonrice 9: 55-61.

2. Prasad, P.V.V., V. Satyanarayana, V.R.K. Murthy and K.J. Boote 2002. Maximizing yields in rice-groundnut cropping sequence through inte-grated nutrient management. Field Crops Res. 75(3):9-21.

3. Bending, G.D., M.K. Turner and J.E. Jones 2002. Interaction between crop residue and soil organic matter quality and the functional diversity of soil microbial communities. Soil Bio-logy \& Biochemistry. 34:1073-1082.

4. Chan, K.Y., D.P. Heenan and H.B. So 2003. Sequestration of carbon and changes in soil quality under conservation tillage on light-textured soils in Australia: a review. Aust. J. Exp. Agr., 43: 325-334.

5. Liu, X., S.J. Herbert, A.M. Hashemi, X. Zhang and G. Ding 2006. Effects of agricultural management on soil organic matter and carbon transformation - a review. Plant Soil Environ. 52(12): 531-543.

6. El-Boraie, F.M., H.K. Abo-El-Ela and A.m. Gaber 2009. Water require-ments of peanut grown in sandy soil under drip irigation and biofertiliztion. Australian Journal on Basic and Applied Science. 3(1): 55-65.

7. Rodriguez, H. and R. Fraga 1999. Phosphate solubilizing bacteria and their role in plant growth promotion. Biotech. Adv. 17: 319-339.
8. Sivan, A. and I. Chet 1992. Microbial control of plant diseases. In: Mitchell $\mathrm{R}$, editor. Environmental Microbio-logy. New York: Wiley-Liss. pp. 335-354.

9. Leong, J. 1986. Siderophores: their biochemistry and possible role in the biocontrol of plant pathogens. Annu. Rev. Phytopathol. 24:187-208.

10. Xie, H., J.J. Pasternak and B.R. Glick 1996. Isolation and characterization of mutants of the plant growth-promoting rhizobacterium Pseudo-monas putida GR12-2 that over-produce indoleacetic acid. Curr. Microbiol. 32:67-71.

11. Christiansen-Weneger, C. 1992. N2-fixation by ammonium-excreting Azospirillum brasilense in auxininduced tumours of wheat (Triticum aestivum L.). Biol Fertil Soils. 12:85100.

12. Bashan, Y. and H. Levanony 1991. Alterations in membrane potential and in proton efflux in plant roots induced by Azospirillum brasilense. Plant Soil. 137:99-103.

13. Glick, .BR., D.M. Penrose and J. Li 1998. A model for the lowering of plant ethylene concentrations by plant growth- promoting bacteria. J. Theor. Biol. 190:63-68.

14. Subba Rao, N.S. 1982. Advances in agricultural microbiology. In: Subba Rao NS, editor. Studies in the Agricultura and Food Sciences. London: Butterworth Scientific, pp. 295-303.

15. Son, T.T.N., L.H. Man, C.N. Diep, T.T.A. Thu and N.N. Nam 2008. Bioconversion of paddy straw and biofertilizer for sustainable rice based cropping systems. Omonrice 16: 57-70. 
16. Suryanarayana-Reddy, R. 1991. Effect of soil amendments on the hardening of red sandy loams (Chalka soils) of Andhra Pradesh. Ann. Agric. Res. 12(2): 174-176.

17. Balakrishnan, V., K. Venkatesan, K. Sanjiviraja, A. Indrajith and K.C. Ravindran 2010. Application of an organic halophytic manure on yield characteristics of Arachis hypogaea Linn. International Journal of Engineering, Science and Techno-logy 2(1):134-143.
18. Waliyar, F. 2005. Aflatoxin contamination in Groundnut in Southern India: Raising awareness and transferring and disseminating technologies to reduce aflatoxin. Final Technical for Report Crop Protection Programme. International Crops Research Institute for the Semi-Arid Tropics (ICRISAT), Patancheru 502 324, Andhra Pradesh, India.

19. Nandagopal, V. and M.P. Ghewande 2004. Use of Neem (Azadirachta indica A. Juss) product in pest management in India. Natural Product Radiance 3(3):150-155. 